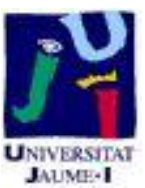

Título artículo / Títol article: Interpersonal trust, stress and satisfaction at work: an empirical study

$\begin{array}{ll}\text { Autores / Autors } & \text { Jacob Guinot } \\ & \text { Ricardo Chiva } \\ & \text { Vicente Roca-Puig }\end{array}$

Revista: $\quad$ Personnel Review, 2014, Vol. 43 Iss 1

Versión / Versió: $\quad$ Pre-print

Cita bibliográfica / Cita Jacob Guinot Ricardo Chiva Vicente Roca-Puig, bibliogràfica (ISO 690): (2014), "Interpersonal trust, stress and satisfaction at work: an empirical study", Personnel Review, Vol. 43 Iss 1 pp. 96 - 115

url Repositori UJI: $\quad$ http://hdl.handle.net/10234/125024 


\section{Interpersonal Trust, Stress and Satisfaction at Work: an Empirical Study}

\section{STRUCTURED ABSTRACT}

Purpose. Due to the divergent conclusions about the effects of interpersonal trust on job satisfaction, the study aims to look more deeply into this relationship by introducing job stress as a mediator variable.

Methodology. We use structural equation modeling to analyze the opinions of 6,407 Spanish employees, taken from the 2008 Quality of Working Life Survey carried out by the Spanish Ministry of Labor and Immigration.

Findings. Our findings show that interpersonal trust has a positive effect on job satisfaction, and that job stress partially mediates this relationship. Furthermore, interpersonal trust is negatively related to job stress, which in turn is negatively related to job satisfaction.

Research limitations/implications. Despite the pertinence and size of the database used in the study, it is very heterogeneous. Future research might delimit the database by organization size or sector. Qualitative studies may also improve our understanding of the relationships studied and enable other concepts to be included. 
Practical implications. Cultivating a climate of trust may provide organizations with a strategy to improve levels of mental well-being and satisfaction among their employees.

Originality/value. This research explains why interpersonal trust has a positive effect on job satisfaction. Our conceptualization of trust implies risk assumption and low risk perception; low perception of risk is presumed to reduce job stress, and in turn, increase job satisfaction. We also put forward reasons for why 'excessive' interpersonal trust has been related to negative effects on job satisfaction. 'Excessive' trust might infer high risk perception, which might increase job stress, and in turn decrease job satisfaction.

Keywords: Interpersonal trust, job stress and job satisfaction.

Paper type: Research paper. 


\section{INTRODUCTION}

Interest in the concept of trust in the organizational environment has grown in recent years as a result of the search for new ways of promoting cooperation among people and groups in organizations, and their attempts to introduce more participative management models (Jones and George, 1998; Mayer et al., 1995).

According to Mayer et al. (1995), trust can be defined as the desire to be vulnerable towards the other party when that party cannot be controlled or monitored. This definition explicitly recognizes the relationship between trust and risk, as making oneself vulnerable involves assuming a risk (Mayer and Gavin, 2005; Mayer et al., 1995). Risk is considered to be an essential condition in all definitions of trust (Rousseau et al., 1998).

Interpersonal trust, namely the trust among the people in the organization, is an extremely complex and dynamic phenomenon (McCauley and Kuhnert, 1992) that has been traditionally associated with favorable consequences for both the staff and the organization (Altuntas and Baykal, 2010). For example, trust has been positively related to organizational performance (Davis et al., 2000) and job satisfaction (Matzler and Renzl, 2006; Perry and Mankin, 2007). However, although organizational researchers have paid special attention to examining the numerous potential benefits of trust, they have devoted significantly less attention to examining the different ways that trust might transmit these benefits (Dirks and Ferrin, 2001). 
Some literature (Gargiulo and Ertug, 2006; Zahra et al., 2006; Molina-Morales et al., 2011) claims that there is a dark side of trust by considering that extreme levels of trust can have negative effects, or that trust can also have dysfunctional effects, when there is an overreliance on some people. Gargiulo and Ertug (2006) suggest that although trust-driven behaviors are generally beneficial, extreme levels of these behaviors can have negative effects. In fact, Zahra et al. (2006) consider that trust can also have dysfunctional effects, when there is an overreliance on some people. As Dirks and Ferrin (2001) claim, trust may actually increase the potential for opportunistic behavior to occur, instead of being a mechanism that mitigates against risk. Excessive levels of trust might bring about negative consequences in job satisfaction. The rationale behind this thinking is that when risk is high, job stress increases (Rafferty and Griffin, 2006; Ulleberg and Rundmo, 1997). And when the worker perceives high levels of risk and stress, job satisfaction is lower. In sum, and according to this dark side of trust approach, high levels of interpersonal trust could be negatively associated with job satisfaction.

Schoorman et al. (2007) highlight the importance of explaining and developing the consequences of interpersonal trust in organizational environments. Research on the level of trust among and between the members of an organization is a critical but under-explored variable (Mayer and Gavin, 2005; Tan and Lim, 2009). In this study we aim to develop a better understanding of how interpersonal organizational trust impacts job satisfaction. In order to do so, we will introduce a mediating variable: job stress, as it seems to be strongly connected to risk assumption and perception. 
In so doing, we will also develop a conceptualization of organizational interpersonal trust that addresses the ambiguity created by the idea that 'excessive trust' has a negative effect on job satisfaction. Although the variables included in the model are well-known and well-documented in the organizational behavior literature, focusing on the effects of interpersonal trust expands our understanding of its role on other variables such as job stress and job satisfaction, and could help to explain how organizations can improve the well-being of their members.

In order to explore this gap, we use data from the 2008 Quality of Working Life Survey conducted by the Spanish Ministry of Labor and Immigration. This introduction to the paper is followed by a brief conceptual background of interpersonal trust, job stress, and job satisfaction. Secondly, we analyze the relationships among these concepts and propose our hypotheses and a theoretical model. Thirdly, we explain the methodology used in the study. We then present our results and conclude by outlining the implications and limitations of the study, and proposals for future research.

\section{CONCEPTUAL BACKGROUND}

\section{Interpersonal organizational trust}

Mayer et al. (1995) define trust as "the willingness of a party to be vulnerable to the actions of another party based on the expectation that the other will perform a particular action important to the trustor, irrespective of the ability to monitor or control that other 
party". Distrust is viewed as the opposite of trust. Scholars consider distrust as an expectation that others will not act in one's best interests, even engaging in potentially injurious behavior (Govier, 1994), and an expectation that capable and responsible behavior from specific individuals will not be forthcoming (Barber, 1983). Therefore, trust refers to confident positive expectations regarding another's conduct, and distrust refers to confident negative expectations regarding another's conduct (Lewicki et al., 1998).

Mayer et al. (1995) understand that trust gives rise to a set of expectations of behavior among people, which allows them to control the uncertainty of the risk associated with their interactions, so that together they can maximize the gains that emerge from cooperative behavior (Jones and George, 1998). Indeed, Mayer et al. (1995) and Schoorman et al. (2007) state that trust leads people to take risks in a relationship. In these terms, Johnson-George and Swap (1982) argue that willingness to take risks is one of the few characteristics common to all situations in which trust is present. Therefore, in order for trust to develop, both parties must be willing to depend on each other and take or assume a risk (Hoe, 2007; Mayer et al., 1995). However, trust is associated with a feeling of control or lower perceived risk (Schill et al., 1980), which means that although trust is linked to assuming a risk, it also requires low risk perception.

Most studies regard trust as a multi-dimensional construct, given that no single dimension properly describes the whole phenomenon (Seppänen et al., 2007). Trust within organizations - or organizational trust—, which embraces two closely related types of trust: people's trust in the organization, and interpersonal trust. McCauley and 
Kuhnert (1992) indicate that interpersonal trust consists of two elements: lateral trust and vertical trust. Lateral trust refers to the trust relationship between a focal employee and his/her co-workers. On the other hand, vertical trust refers to the trust relationship between a subordinate and his/her direct supervisor. Similarly, Ting (1997) argued that there are two types of interpersonal trust, separating supervisory trust from trust in coworkers. These sub-categories of interpersonal organizational trust imply there are different dimensions of social relationships among workers in the workplace. Trust in others can be broken down into several categories according to types of others, such as employer and co-workers in the workplace. An employee may trust his or her coworkers but distrust his or her supervisor. Therefore, in this study, interpersonal organizational trust includes trust in supervisors and trust in co-workers.

Interpersonal trust has also an affective base and a cognitive base (Lewis and Wiegert, 1985; McAllister, 1995). The rational decision to trust the other party involves the cognitive base of trust. This decision is based on qualities such as responsibility, dependability and competence, and puts the other party's trustworthiness to the test (Lewis and Wiegert, 1985; Costigan et al., 1998). Cognition-based trust is trust derived from the beliefs that another party is dependable, reliable, responsible, and competent (Lewis and Wiegert, 1985; McCallister, 1995). On the other hand, affect-based trust is grounded in the emotional links between individuals (Lewis and Weigert, 1985). Affectbased trust involves reciprocated interpersonal care and concern for another person (Pennings and Woiceshyn, 1987; Rempel et al., 1985), subjective feelings of security against being exploited, and the comfort and assurance that one's interests are being served by another party (Mittal, 1996; Massey and Kyriazis, 2007). 


\section{Job stress}

Generally, job stress is understood to be the feeling of personal dysfunction an employee experiences as a result of perceived conditions or events that occur in the workplace; in other words job stress is the psychological and physiological responses caused by a work setting in which the worker feels uncomfortable, unwanted or threatened (Montgomery et al., 1996; Chen and Silverthorne, 2006).

Stress is a multi-dimensional concept can occur if there is a mismatch between the demands placed on an individual and his or her abilities to meet those demands. A misfit between the objective reality of the work environment and an individual's subjective perceptions of the work environment can result in job stress. However, stress is not necessarily a negative phenomenon. Literature establishes two major types of stress: eustress (good stress) and distress (bad stress) (Fevre et al., 2003; Sullivan and Bhagat, 1992). In terms of eustress perspective, job stress occurs when employees' knowledge, skills, abilities and attitudes can cope with or match to their work demands and pressures in organizations. In this situation, it may increase the ability of employees to manage their physiological and psychological stresses (Adler et al., 2006; Cartwright and Cooper, 1997; Wetzel et al., 2006). 
Conversely, in a distress perspective, job stress presents when employees' knowledge, skills, abilities and attitudes cannot cope with or do not match to their work demands and pressures in organizations. Consequently, it may decrease the ability of employees to control and manage physiological and psychological stresses, such as disturb their self-regulatory bodies, and cannot meet their duties and responsibilities as a member of an organization (Cox et al., 2000; Fairbrother and Warn, 2003; Critchley et al., 2004).

Studies into job stress indicate that several different job conditions determine the level of stress workers experience. According to Weinberg et al. (2010), the main sources of stress - or stressors — in the workplace are: the demands of the job (work load, working hours, system changes, the work-life balance, the demands of the physical work setting); control at work (the way of working, the importance of participation in decisions, and skill improvement); lack of support at work; poor work relationships, mostly based on distrust; and changes in the job and in the organization. Among the job conditions that are potential sources of stress for workers are the interpersonal or psychosocial features of the work situation. Weinberg et al. (2010) point to the lack of support in relationships at work or poor relationships with co-workers as potential sources of job stress. These authors also note that poor interpersonal relationships can be harmful to workers' psychological well-being, as they entail low levels of trust and support among the parties involved.

\section{Job satisfaction}

Locke (1976) defines job satisfaction as a positive or pleasant emotional state resulting from the subjective perception of one's work experiences. Job satisfaction is considered 
to be highly subjective and varies according to time (Cumbey and Alexander, 1998). Job satisfaction is mainly defined as the affective orientation that an employee has toward his or her work as a global feeling about various aspects or facets of the job (Lu et al., 2005; Hwang and Chang, 2008). Hackman and Oldham (1975) argued that job satisfaction includes general elements and specific elements: the whole perception of job pleasure is considered as general elements; job security, pay, co-worker, supervision and personal growth and development are considered as specific elements. The most accepted and common facets of satisfaction (Judge et al., 2001) are satisfaction with pay, promotion opportunities, coworkers, supervision, and the work itself (Smith et al., 1969). These five job facets typically account for a substantial amount of the variance in overall job satisfaction (Kinicki et al., 2002; Rogelberg et al., 2010).

According to the situation approach of job satisfaction, the interaction of variables such as task characteristics, organizational characteristics, and individual characteristics influence job satisfaction. The situational approach of job satisfaction (Hackman and Oldman, 1980; Herzberg, 1966) understands that job satisfaction is mainly influenced by working and organizational conditions. Furnham (1992) categorizes factors that can have an influence on job satisfaction into three groups: organizational policies and procedures (remuneration package, supervision and decision-making practices, and the perception of the quality of supervision), task or job characteristics (aspects of the total workload, the variety of skills applied, autonomy, feedback and the physical nature of the working environment), and personal aspects (self-image, ability to deal with stress and general satisfaction with life). 


\section{RESEARCH HYPOTHESES}

In this section we present the conceptual model of the hypotheses on the relationships between interpersonal trust, job stress, and job satisfaction. The model proposes that the effect of interpersonal trust on job satisfaction is partially mediated by organizational stress (Figure 1). To this end we propose three hypotheses describing (a) the relationships between interpersonal trust and job satisfaction, (b) the relationship between interpersonal trust and job stress, and (c) the relationship between job stress and job satisfaction.

Insert Figure 1

Interpersonal trust and job satisfaction: a case of the partial mediation of job stress

Accumulating evidence seems to agree that trust has a number of important benefits for organizations and their members (Dirks and Ferrin, 2001). Trust has favorable consequences for all relationships formed within an organization (Altuntas and Baykal; 2009). According to Rhee (2010) trust in others in the workplace is a proxy indicator of human relationships among various members in a workplace. Cook and Wall (1980:39) conclude that "trust between individuals and groups within organizations is a highly important ingredient in the long-term stability of the organization and the well-being of 
its members." Studies into the effects of interpersonal trust have found that it helps create more positive attitudes in the workplace, including satisfaction with the job and commitment at work (Dirks and Ferrin, 2001, 2002; Mooradian et al., 2006). Individuals working in an organization where a high level of confidence is present perceive themselves as a valued and important part of the organization, come to work with more enthusiasm, and are happier with their jobs (Altuntas and Baykal, 2009).

According to Dirks and Ferrin (2001), prior studies make two fundamental distinctions regarding how these effects occur. The dominant perspective is that trust results in direct (main) effects on a variety of outcomes. Several studies analyzing the bosssubordinate relationship have also found that trust has a direct effect on job satisfaction (Lagace, 1991; Brashear et al., 2003). Examples include Rich (1997), who shows that sales personnel are more satisfied with their jobs if they have honest bosses in whom they can place their trust; or Flaherty and Pappas (2000) who analyze the salespersonmanager relationship and conclude that trust has a major repercussion on job satisfaction. Likewise, in an empirical study in two firms Goris et al. (2003) find that interpersonal trust is a determinant factor in job satisfaction. Matzler and Renzl (2006) report that trust in co-workers and in superiors are both strong drivers of job satisfaction. In a study analyzing the relationships among organizational trust, trust in management and job satisfaction, Perry and Markin (2007) conclude that organizational trust is positively related to job satisfaction, showing that when organizations are accorded with higher levels of trust, job satisfaction tends to be higher than in organizations where trust levels are lower. 
While studies examining the main effects of trust are dominant in the literature, this perspective not represent the only way that trust might have positive consequences. Although scholars have assumed that trust has a direct effect on a variety of outcomes, trust also provides the conditions under which certain outcomes are likely to occur. Dirks and Ferrin (2001) developed an alternative model that describes how trust might transmit these benefits for organizations. According to this model, trust facilitates the effects of other determinants on desired outcomes within organizational settings. This perspective has received scant attention compared to the main effect model (Dirks and Ferrin, 2001).

Dirks and Ferrin (2001) provides a framework for better understanding past research on the consequences of trust, suggesting that in some cases trust may simultaneously produce a main and moderating effect and that additional research is needed to better understand the effects of trust in organizational settings. Accordingly, this study explores the routes through which trust might produce positive effects on other organizational variables such as job stress and job satisfaction. Moreover, the literature review indirectly suggests a negative relationship between trust and job stress and in turn a negative relationship between stress and job satisfaction.

Taking into account all these considerations lead us to propose our first hypothesis:

Hypothesis 1: The relationship between interpersonal trust and job satisfaction is partially mediated by job stress. 


\section{Interpersonal trust and job stress}

High levels of interpersonal trust imply that the parties care about each other, listen to problems, and the manager provides coaching advice and consistent feedback. People who trust each other are also likely to be more willing to synchronize, help each other, and work together constructively (Lau and Tan, 2006). According to Lau and Tan (2006), this is likely to increase their commitment to each other and such congenial relationships will tend to lead to lower levels of stress, anxiety and tension in the workplace. In contrast, distrust leads to feelings of insecurity, uncertainty, and anxiety (Carlson and Perrewe, 1999; Gambetta, 1988).

Predominantly destructive relationships based on mistrust and scant cooperation, coworker rivalry over more advantageous conditions or positions, lack of emotional support in difficult situations or even the absence of any relationships among peers, and lack of consideration and favoritism on the part of superiors can produce high levels of stress among the members of a group or organization (Lazarus, 1966; McLean, 1979; Beehr, 1981). Moreover, inconsiderate behavior on the part of supervisors or lack of support for their subordinates significantly contributes to creating a feeling of pressure at work (Buck, 1972; McLean, 1979).

The literature suggests that stress is a feeling created by perceptions (Lazarus and Folkman, 1984; Rafferty and Griffin, 2006). Rhee (2010) affirms that the different dimensions of trust in a workplace can influence job stress and the perception of and reaction to job stress. Several studies confirm the relationship between risk perception 
and job stress (e.g. Rafferty and Griffin, 2006; Ulleberg and Rundmo, 1997). This notion is also supported by Beehr and Bhagat (1985), who noted that the severity of stress increases when there is a high level of uncertainty over a prolonged period of time. In fact, risk perception has been positively related to job stress (Rafferty and Griffin, 2006; Ulleberg and Rundmo, 1997). This indicates that risk perception will have a major impact on job stress. Therefore, when employees' risk perception increases, their job stress levels rise accordingly.

Although trust is associated with risk assumption, it also implies a lower perceived risk or feeling of control, both of which can increase certainty about the future and reduce stress (Groen and Bastiaans, 1975; Schill et al., 1980). Some research appears to endorse the idea that stress can be reduced by the social support of others in the form of interpersonal trust within the organization (Beehr and McGrath, 1992; McLean, 1979). Likewise, Schill et al. (1980) find that increased trust improves the ability to cope with stressful life events. Potentially, therefore, high levels of trust can reduce job stress. Given that interpersonal trust reduces uncertainty and perception of risk in social relationships (Jones and George, 1998), we might therefore suppose that trust can help reduce job stress. In sum, trust, therefore, appears to be negatively related to stress, which leads us to our second hypothesis:

Hypothesis 2: Interpersonal trust is negatively related to job stress. 


\section{Job stress and job satisfaction}

In general, job stress has been viewed as an antecedent of job satisfaction, and these two constructs have been treated as related yet distinct (Stanton et al., 2002). Outcomes of stress include psychological strains, which can be defined as deviations from normal functioning (Edwards et al., 1998), and one such psychological strain is job dissatisfaction. Studies in this area show that the ability of employees to manage their physiological and psychological stresses may have a significant impact on job satisfaction (Fairbrother and Warn, 2003; Snelgrove, 1998; Swanson et al., 1998).

As we said, eustress may increase the ability of employees to manage their physiological and psychological stresses. Conversely, distress may decrease the ability of employees to control and manage physiological and psychological stresses. In turn, the ability of employees to properly control and manage their physiological and psychological stresses in performing job may lead to higher job satisfaction in organizations (Antoniou et al., 2003; Fairbrother and Warn, 2003; Stacciarini, 2004). Thus, if employees cannot control such stresses this may negatively affect their work attitudes and behavior in the workplace including job satisfaction (Seaward, 2005; Newell, 2002; Ismail et al., 2009).

Similarly, Landsbergis (1988) and Terry et al. (1993) showed that high levels of work stress are associated with low levels of job satisfaction. Moreover, Cummins (1990) have emphasized that job stressors are predictive of job dissatisfaction. However, although the nature of this relationship is significant, little is known about the role of 
job stress as a determinant of job satisfaction in the workplace stress research literature (Guleryuz et al., 2008; Stacciarini et al., 2004). Thus, in light of the above we propose the following hypothesis:

Hypothesis 3: Job stress and job satisfaction are negatively related.

\section{METHODOLOGY}

\section{Sample}

The data used in this study were taken from the 2008 Quality of Working Life Survey carried out by the Spanish Ministry of Labor and Immigration and included in the National Statistics Plan for the period 2005-2008. The aim of this survey is to investigate the quality of life of Spanish workers by using, on the one hand, information on the situation and activities that arise in their work and home environments, and on the other hand, subjective information on workers' personal perceptions of their work conditions and relationships. This survey is carried out across the whole of Spain. Given the high number of respondents, this survey provides very relevant and representative information of the workers' situation in the Spanish labor market and of the workers' perceptions of their labor relations and conditions. Consequently, this survey has been used by numerous research projects (e.g. Ollo-Lopez et al., 2010; Peraita and Pastor, 2000). The theoretical sample size at national level is 9,600 employees; once atypical 
cases and cases with missing data for the variables used in this empirical analysis were removed, 6,407 cases remained.

\section{Measurement of the variables}

Some of the questions from the above-mentioned 2008 Quality of Working Life Survey referring to the concepts analyzed in this study were used to measure the study variables of interpersonal organizational trust, job stress and job satisfaction.

Interpersonal organizational trust. We used two indicators from the 2008 Quality of Working Life Survey that evaluate the "degree of trust in your superiors" and the "degree of trust in the co-workers from the same level as yourself", both measured on a Likert scale (0: none; 10: very high). Some previous empirical research (e.g., Shah, 1998) has also used only one item to measure interpersonal trust. Moreover, more recent studies (Wu et al., 2009; Oh and Park, 2011), suggest that workers' interpersonal trust can be measured in terms of trust in supervisors and trust in co-workers. The unidimensionality of the scale was tested using principal components analysis with varimax rotation, which resulted in a single factor with a value in excess of the unit that explained 75.182 percent of the total variance. Bartlett's test of sphericity $(\mathrm{p}<0.001)$ demonstrated the advisability of this analysis. Bartlett's test of sphericity tests whether the correlation matrix is an identity matrix, which would indicate that the factor model is appropriate. The scale's internal consistency was also verified by means of Cronbach's alpha coefficients (0.655), which indicate the degree to which a set of items measures a 
single unidimensional factor construct. According to DeVellis (1991), an alpha coefficient between 0.65 and 0.70 can be considered as minimally acceptable. Indeed, when a measure has other desirable properties, such as meaningful content coverage of some domain and reasonable unidimensionality, this low reliability may not be a major impediment to its use (Schmitt, 1996). The two indicators make up the latent factor of interpersonal trust.

Job stress. The level of stress was also measured with a single item: "the level of stress you experience in your job" on a Likert scale from 0 (none) to 10 (very high). Previous research has also used this type of scale to measure levels of job stress (e.g., Langford, 2003) and can therefore be considered as a valid measurement. According to these prior studies we could use this single question item to reflect the meaning of job stress.

Job satisfaction. As in the previous cases, employees were asked to respond to a single item: "indicate your degree of satisfaction with your present job", on a Likert scale (0: none - 10: very high); job satisfaction was thus considered as an overall perception of the job (Spector, 1997). General job satisfaction was therefore measured by a single item, as in previous studies (Wanous et al., 1997; Ganzach, 1998; Chiva and Alegre, 2009). Ganzach (1998) explains that although the measurement of a variable by a single item has frequently been called into question, it may have higher validity than cases where various items are used, without any loss of reliability (Wanous et al., 1997). 
Control variable. Employee age was used as the control variable. Some studies have found a significant and positive relationship between age and job satisfaction (e.g. Kalleberg and Loscocco, 1983; Bos et al., 2009), showing that job satisfaction increases with age. Age differences may therefore have an effect on job satisfaction.

Additionally, we assessed the probable extent of common method variance. Common method bias can be a problem when dependent and independent variables are collected from a single informant. According to Harman's single factor test (Podsakoff and Organ, 1986), if common method variance exists a single factor will emerge from a factor analysis of all survey items. To test the problem of common method variance we estimated a single factor model with all survey items. The results of this factor model ( $\chi^{2}$ Satorra-Bentler: 15.944 , d.f. $\left.5, p .0 .007\right)$ indicated that common method variance was not a serious problem.

\section{RESULTS}

Table 1 presents the descriptive statistics of the indicators considered in the study. Structural equation modeling (SEM) was used to analyze the theoretical model, using the statistical program EQS 6.1 for Windows. The results confirm an adequate fit of the model with the data used (Satorra-Bentler Chi-Square $=10.547$; degrees of freedom $=$ 4; $\mathrm{p}=0.032$; Bentler-Bonnet Non-Normed Fit $=0.995$; Index Comparative Fit Index: 0.998; root mean square error of approximation $=0.016$ ). Results for the regression coefficients of the model indicate a positive relationship between interpersonal trust and 
job satisfaction $(\beta 1=0.624, \mathrm{t}=26.336, \mathrm{p}<0.01)$, therefore supporting hypothesis $\mathrm{H} 1$. A negative relationship was found between interpersonal trust and job stress $(\beta 2=-$ $0.165, \mathrm{t}=-9.963, \mathrm{p}<0.01)$, thus confirming hypothesis $\mathrm{H} 2$, and also showed that job stress has a negative effect on job satisfaction $(\beta 3=-0.026, \mathrm{t}=-2.114, \mathrm{p}<0.05)$, confirming hypothesis H3. The results obtained therefore verify all the hypotheses proposed in our model.

Insert Table 1

Insert Figure 2

In order to examine whether the job stress variable mediates in the relationship between interpersonal trust and job satisfaction, we followed the procedure described by BeltránMartín et al. (2008), which involves estimating two structural models. The first is a direct effects model that tests the effect of independent variables on dependent variables. For this mediation to exist, the coefficient in the direct effects modelreferring to the effect of interpersonal trust on job satisfaction-must be significant for testing of the mediator effect to continue. The second model is a mediated model that includes the mediator variable. This model estimates the effects of interpersonal trust on job stress, the impact of stress on job satisfaction, and the direct effect of interpersonal trust on job satisfaction (Figure 2). To test whether the mediator effect of job stress is partial or total, we compared the mediated model to the constrained model in which the 
coefficient between interpersonal trust and job satisfaction ( $\beta 1$ in the mediated model) was equal to zero. This allowes us to see whether the mediated model achieves a significant improvement in fit over the constrained model. If job stress causes a total mediator effect, the coefficient of the relationship between trust and job satisfaction included in the constrained model will not improve the fit. In the opposite case, the mediation would be partial.

The fit indexes for the models are presented in Table 2. In the direct effects model, we confirmed that the coefficient of the relationship of interpersonal trust on job satisfaction is significant $(\beta 1=0.629, \mathrm{p}<0.01)$. The $\chi^{2}$ test of differences between the mediated model and the constrained model showed a statistically significant difference in the $\chi^{2}(\mathrm{p}<0.01)$. The relationship between interpersonal trust and job satisfaction in the mediated model significantly improves the fit of the constrained model, thus evidencing the partial mediation effect of job stress in the model. Consequently, interpersonal trust affects job satisfaction both directly and indirectly (through job stress). In particular, a positive indirect effect $(\beta=0.006 ; t=1.98 ; p<0.05)$ is seen between these two variables. The contribution of the mediated model in terms of the effect of interpersonal trust on job satisfaction lies in the analysis of job stress as a mechanism that mediates this relationship and allows the information provided by the direct effects model to be extended.

Insert Table 2 


\section{DISCUSSION}

Trust among members of an organization is traditionally considered as one of the key factors enabling organizations to face the complexity and uncertainty of today's new scenarios (Bachmann and Zaheer, 2006). However, this study was carried out in response to calls from some authors to analyze the indeterminate consequences of trust in organizational environments (Schoorman, 2007).

Most of the literature considers that trust has a positive effect on individuals' job satisfaction (Matzler and Renzl, 2006; Brashear et al., 2003; Perry and Mankin, 2007). However, some authors have identified a dark side of trust (Gargiulo and Ertug, 2006; Zahra et al., 2006; Molina-Morales et al., 2011). According to this approach, very high levels of trust can have negative effects on employees' job satisfaction. Indeed, although trust in organizations continues to excite considerable interest among organizational researchers (e.g. Bachmann and Zaheer, 2006; Dirks et al., 2009; Kramer and Lewicki, 2010; Schoorman et al., 2007), research on this topic still remains limited (Tan and Lim, 2009). Although numerous researches seem to agree that trust has important benefits for organizations and his members, is necessary to examining the different ways that trust might transmit these benefits occur (Dirks and Ferrin, 2001). Through this study we have tried to shed some light on the effects of trust within organizations.

In order to analyze the relationship between interpersonal trust and job satisfaction, we introduced a new variable: job stress. As we argued that job stress is intrinsically related 
to risk (Beehr and Bhagat, 1985), which is implicit in trust, it can help us to better understand how interpersonal trust affects job satisfaction and consequently, we considered job stress as a mediating variable. Therefore, the aim of this research was to examine the previously unexplored relationship between interpersonal trust, job stress and job satisfaction. To this end, we used 6,407 responses to a questionnaire designed by the Spanish Ministry of Labor and Immigration. Our results reveal a positive relationship between interpersonal trust and job satisfaction, and furthermore, this relationship seems to be partially mediated by job stress. Negative relationships were found between interpersonal trust and job stress, and between job stress and job satisfaction. This partial mediation illustrates the complexity of the concept of trust.

We consider that interpersonal trust, or the trust among people in the organization, can be understood as the assumption of risks from the other party, and simultaneously the perception of low risks (Mayer et al., 1995; Schill et al., 1980). Consequently, when individuals trust other people, they have a feeling of control due to their low perception of risk (Schill et al., 1980). At the same time, when employees properly control and manage their physiological and psychological stresses in performing job may feel higher job satisfaction (Antoniou et al., 2003; Fairbrother and Warn, 2003; Stacciarini, 2004). Therefore, this low perception of risk and feeling of control produced by trust might reduce job stress, which in turn increases job satisfaction.

This rationale and conceptualization of trust allows us to suggest why some literature considers that excessive trust can decrease job satisfaction. As we 
mentioned above, we consider that interpersonal trust implies risk assumption and also low risk perception. Individuals take risks concerning other people, but sometimes they have neither a low perception of risk nor a feeling of control, which might imply, according to our conceptualization, that they do not really trust them. Consequently, their job stress levels increase and, in turn, their job satisfaction declines. Therefore, 'excessive' trust might bring about negative consequences for job satisfaction. According to our definition, trust would then not exist, and due to the high perception of risk might be perceived as 'excessive' trust.

In order for trust to be developed, all involved parties must be willing to rely on each other and take risks (Mayer et al., 1995). Trust, therefore, involves accepting these risks, together with one's own vulnerability to the actions of others (Rousseau et al., 1998), essentially because when we trust others, we perceive fewer risks and less uncertainty (Schill et al., 1980; Jones and George, 1998). This lower perception of risk-or the unconscious acceptance of risk-reduces tension, which in turn leads employees to perceive their working environment as less uncomfortable, unwanted or threatening, all of which reduce job stress. This study therefore demonstrates how, if positive expectations of the intentions and behaviors of others can be generated, based on the existence of mutual trust between parties, job stress levels fall, and as a result, job satisfaction rises (e.g., Igharia and Greenhaus, 1992; Ahsan et al., 2009).

\section{Managerial implications}


According to the results of this study, when mutual trust spreads among all the people in an organization-regardless of whether they belong to the same hierarchical level or not - job stress can be reduced, and levels of job satisfaction can rise. Trust can be considered as a crucial component of professional life as it has favorable consequences for both the staff and the organization (Altuntas and Baykal, 2010). Increased trust within organizations improves the ability of workers to cope with stressful life events and be more satisfied in their jobs. Our research shows how one way to reduce job stress among organizational members is to increase the subordinates' trust in their supervisors and trust between workers within the same hierarchical level. Therefore, fostering a climate of trust within organizations can be used as a strategy by CEOs or human resources managers to improve levels of psychological well-being and satisfaction among their workers.

\section{Limitations and directions for future research}

The conclusions drawn from this study are based on data taken from the 2008 Quality of Working Life Survey carried out by the Spanish Ministry of Labor and Immigration and covering the whole of Spain. Despite the pertinence and size of the database used, it is very heterogeneous, since the employees surveyed belong to companies and organizations of many different sizes and sectors. Future research could focus on more specific organizations determined by size or sector. 
Another limit on this study is the causal direction between the constructs raised in the model. The cross-sectional nature of our study does not allow inferences about the causality in the observed associations. This is a common limitation of cross-sectional studies, so that longitudinal-type studies are necessary in order to ascertain the direction of causality in these relationships.

We believe that qualitative studies could help to provide a better understanding of the relationships among the three concepts studied, and could include other concepts such as human resource management. This is an initial theoretical model, and the first step in exploring these relationships, and as such, it could be used as a framework for subsequent refinement.

\section{REFERENCES}

Abrams, L.C., Cross, R., Lesser, E. and Levin D. Z. (2003), "Nurturing interpersonal trust in knowledge-sharing networks, Academy of Management Executive", Vol. 17, No 4; pp. 64-77.

Adler, D.A., McLaughlin, T.J., Rogers, W.H., Chang, H., Lapitsky, L., and Lerner, D. (2006), "Job performance deficits due to depression", The American Journal of Psychiatry, 163, 1569- 1576.

Ahsan, N., Abdullah, Z., Yong Gun Fie, D. and Shah Alam, S. (2009), “A Study of Job Stress on Job Satisfaction among University Staff in Malaysia: Empirical Study", European Journal of Social Sciences, Vol. 8, No. 1, pp. 121-131.

Altuntas, S. and Baykal, U. (2010), "Relationship Between Nurses' Organizational Trust Levels and Their Organizational Citizenship Behaviours". Journal of Nursing Scholarship, 42(2), 186-194.

Antoniou, A.S.G., Davidson, M.J., and Cooper, C.L. (2003), "Occupational stress, job satisfaction and health state in male and female junior hospital doctors in Greece", Journal of Managerial Psychology, 18(6), 592-621. 
Babin, B.J. and Boles, J.S. (1996), "The effects of perceived co-worker involvement and supervisor support on service provider role stress, performance and job satisfaction", Journal of Retail, Vol. 72, No.1; pp. 57-75.

Bachmann, R. and Zaheer, A. (2006), Handbook of Trust Research. Cheltenham, UK, Northampton, MA : Edward Elgar.

Barber, B. (1983), The logic and limits of trust. New Brunswick, NJ: Rutgers University Press.

Beehr, T.A. (1981), "Work-role stress and attitudes towards coworker", Group and Organizational Studies, Vol. 6, pp. 201-210.

Beehr, T.A. and Bhagat, R.S. (1985), Human Stress and Cognition in Organisations, John Wiley, New York, NY.

Beehr, T.A. and McGrath, J.E. (1992), "Social support, occupational stress and anxiety", Anxiety, Stress and Coping, Vol. 5, pp. 7-19.

Bell, G.G., Oppenheimer, R.J. and Bastien, A. (2002), "Trust deterioration in an international buyer-supplier relationship", Journal of Business Ethics, Vol. 36, No. 1/2, pp. 65-78.

Beltrán-Martín, I., Roca-Puig, V., Escrig-Tena, A. and Bou-Llusar, J.C. (2008), "Human resource flexibility as a mediating variable between high performance work systems and performance", Journal of Management, Vol. 34, No. 5; pp. 1009-44.

Bews, N. and Martins, N. (2002), "An evaluation of the facilitators of trustworthiness" South African Journal of Industrial Psychology, Vol. 28, No 4, pp. 14-19.

Bönner, K. (1967), Industrial Implications of Stress, New York: American Elsevier Pub.

Bos, J.T., Donders, N., Bouwman-Brouwer, K.M. and Van der Gulden, J. (2009), "Work characteristics and determinants of job satisfaction in four age groups: university employees' point of view", Int Arch Occup Environ Health, Vol. 82, pp. 1249-1259.

Brashear, T.G., Boles, J.S. and Brooks, C.M. (2003), "An empirical test of trustbuilding processes and outcomes in sales manager-salesperson relationships", Journal of the Academy of Marketing Science, Vol. 31 No. 2, pp. 189-200.

Buck, V. (1972), Working Under pressure, London, Staples Press.

Buunk, B. P., de Jonge, J., Ybema, J.F. and de Wolff, C.J. (1991), "Psychosocial Aspects of Occupational Stress", in P.J.D. Drenth, H. Thierry \& C.J. de Wolff (Eds.), Handbook of Work and Organizational Psychology, 145-182.

Cartwright, S., and Cooper, C.L. (1997), Managing workplace stress, Thousand Oaks, California: Sage Publications. 
Carlson, D. S. and Perrewè, P. L. (1999), "The role of social support in the stressorstrain relationship: An examination of work-family conflict", Journal of Management, 25, 513-540.

Chen, J.-C., Silverthorne, C. and Hung, J.-Y. (2006), "Organization communication, job stress, organizational commitment, and job performance of accounting professionals in Taiwan and America", Leadership and Organization Development Journal, Vol. 27, No. 4, pp. 242-249.

Chiva, R. and Alegre, J. (2009), "Organizational Learning Capability and Job Satisfaction: an Empirical Assessment in the Ceramic Tile Industry", British Journal of Management, Vol. 20, pp. 323-340.

Conti, R., Angelis, J., Cooper, C., Faragher, B. and Gill, C. (2006), "The effects of lean production on worker job stress", International Journal of Operations \& Production Management, Vol. 29, No. 9, pp. 1013-1038.

Cook, J. and Wall, T. (1980), "New work attitude measures of trust, organizational commitment and personal need non-fulfillment", Journal of Occupational Psychology, (53), 39-52.

Cooper, C.L. (1973), Group Training of Individual and Organizational Development, Basle: S. Karger.

Costigan, R. D., Ilter, S. S. and Berman, J. J. (1998), "A Multi-Dimensional Study of Trust in Organizations”, Journal of Management Issues, 10(3): 303-317.

Cox, T., Griffiths, A., and Rial-González, E. (2000), Research on Work- Related Stress, Luxembourg: Office for Official Publications of the European Communities.

Cranwell-Ward, J. (1998), "Stress", in Poole, M., Warner, M. (Eds), The Handbook of Human Resource Management, International Thomson Business Press, London.

Critchley, H.D., Rotshtein, P., Nagai, Y., O’Doherty, J., Mathias, C.J., and Dolan, R.J. (2004), "Activity in the human brain predicting differential heart rate responses to emotional facial expressions", NeuroImage, 24, 751-762.

Cumbey, D., and Alexander, J. (1998), "The relationship of job satisfaction with organizational variables in public health nursing", Journal of Nursing Administration, 5, $39-46$.

Cummins, R.C. (1990), "Job stress and the buffering effort of supervisory support", Group and Organizational Studies, Vol. 15 No. 1, pp. 92-104.

Curseu, P.L. and Schruijer, S.G.L. (2010), "Does conflict shatter trust or does trust obliterate conflict? Revisiting the relationships between team diversity, conflict, and trust", Group Dynamics: Theory, Research and Practice, Vol. 14, No. 1, pp. 66-79. 
Davis, J. H., Schoorman, F. D., Mayer, R. C., and Tan, H. H. (2000), "The trusted general manager and business unit performance: Empirical evidence of a competitive advantage", Strategic Management Journal, 21: 563-576.

DeLongis, A., Folkman, S. and Lazarus, R. S. (1988), "The impact of daily stress on health and mood: Psychological and social resources as mediators", Journal of Personality and Social Psychology, Vol. 54, pp. 486-496.

Deluga, R.J. (1994), "Supervisor trust building, leader-member exchange and organisational citizenship behavior", Journal of Occupational and Organisational Psychology, Vol. 64, No. 4, pp. 316-327.

DeVellis, R. F. (1991), Scale development: Theory and applications, Newbury Park, CA: Sage.

Dirks, K. T. and Ferrin, D. L. (2001), "The role of trust in organizational settings", Organization Science, Vol. 12, No. 4, pp. 450-467.

Dirks, K. T. and Ferrin, D. L. (2002), "Trust in leadership: meta-analytic findings and implications for research and practice", Journal of Applied Psychology, Vol. 87, No. 4, pp. 611-628.

Dirks, K.D., Lewicki, R.J. and Zaheer, A. (2009), "Repairing relationships within and between organizations: Building a conceptual foundation", Academy of Management Review, 34(1), 68-84.

Edwards, J. R., Caplan, R. D., and Harrison, R. V. (1998), "Person-environment fit theory: conceptual foundations, empirical evidence, and directions for future research". In C. L. Cooper (Ed.), Theories of organizational stress (pp. 28-67). New York: Oxford University Press.

Fairbrother, K., and Warn, J. (2003), "Workplace dimensions, stress and job satisfaction”, Journal of Managerial Psychology, 18 (1), 8-21.

Fevre, M.L., Matheny, J., and Kolt, G. S. (2003), "Eustress, distress and interpretation in occupational stress", Journal of Managerial Psychology, 18 (7), 726-744.

Flaherty, K. E. and Pappas, J. M. (2000), "The role of trust in salesperson-sales manager relationships", Journal of Personnel Selling and Sales Management, Vol. 20, No. 4, pp. 271-278.

Fox, A. (1974), Beyond Contract: Power and Trust Relations, London: Faber \& Faber.

Furnham, A. (1992), Personality at Work: the Role of Individual Differences in the Workplace, Routledge, London.

Gambetta, D. (1988), Trust: Making and breaking co-operative relationships, New York: Basil Blackwell, Inc. 
Ganzach, Y. (1998), "Intelligence and job satisfaction", Academy of Management Journal, Vol. 41, pp. 526-539.

Gargiulo, M. and Ertug, G. (2006), "The dark side of trust", In R. Bachmann \& A. Zaheer (Eds.), Handbook of trust research: 165-186, MA: Edward Elgar.

Goris, J. R., Vaught, B. C. and Pettit, J. D. (2003), "Effects of trust in superiors and influence of superiors on the association between individual job congruence and job performance/satisfaction", Journal of Business and Psychology, Vol. 17, No. 3, pp. 327-343.

Groen, J.J. and Bastiaans, J. (1975), "Psychosocial stress, interhuman communication and psychosomatic disease", in D.C. Spielberger e I.G. Sarason, Stress and Anxiety, vol. 1, (pp.27-49), Washington D.C.: Hemisphere.

Govier, T. (1994), "Is it a jungle out there? Trust, distrust and the construction of reality", Dialogue, Vol. 33, pp. 237-57.

Guleryuz, K., Guney, S., Aydin, E.M., and Asan, O. (2008), "The mediating effect of job satisfaction between emotional intelligence and organizational commitment of nurses: a questionnaire survey", International Journal of Nursing Studies, 45(11), 16251635.

Hackman, J. R. and Oldham, G. R. (1975), Development of the Job Diagnostic Survey. Journal of Applied Psychology, 60, 159-170.

Hackman, J. R. and Oldham, G. R. (1980), Work redesign, Reading, MA: Addison Wesley.

Herzberg, F. (1966), Work and the Nature of Man, Cleveland: World Publishing Company.

Herzberg, F. (2003), “One More Time: How Do You Motivate Employees?” Harvard Business Review, January - Special issue, pp. 87-96.

Hoe, S. L. (2007), "Is interpersonal trust a necessary condition in organisational learning?", Journal of Organizational Transformation and Social Change, Vol.4, No. 2, pp. 149-156.

Hwang, J.I. and Chang, H. (2008), "Explaining turnover intention in Korean public community hospitals: occupational differences", International Journal of Health Planning and Management, 23, 119-138.

Igharia, M. and Greenhaus, J. H. (1992), "Determinants of MIS Employees' turnover intentions: A Structural Equation Model", Communications of the ACM, 35(2), pp.3449. 
Ismail, A., Yao, A., and Yunus, N. K. (2009), "Relationship between occupational stress and job satisfaction: An empirical study in Malaysia", The Romanian Economic Journal, 34 (4), 3-29.

Johnson-George, C. and Swap, W. C. (1982), "Measurement of specific interpersonal trust: Construction and validation of a scale to assess trust in a specific other", Journal of Personality and Social Psychology, Vol. 43, pp. 1306-1317.

Jones, G. R. and George, J. M. (1998), "The experience and evolution of trust: Implications for cooperation and teamwork", Academy of Management Review, Vol. 23, No. 3, pp. 531-546.

Judge, T. A., Thoresen, C. J., Bono, J. E., and Patton, G. K. (2001), "The job satisfaction-job performance relationship: A qualitative and quantitative review", Psychological Bulletin, 127, 376-407.

Kalleberg, A. and Loscocco, K. (1983), "Aging, values, and rewards: Explaining age differences in job satisfaction", American Sociological Review, Vol. 48, No. 1, pp. 7890 .

Kemery, E., Bedeian, A., Mossholder, K. and Touliatos, J. (1985), "Outcomes of role stress: a multisample constructive replication", Academy of Management Journal, Vol. 28, pp. 63-75.

Kinicki, A. J., McKee-Ryan, F. M., Schriesheim, C. A., and Carson, K. P. (2002), "Assessing the construct validity of the job descriptive index: A review and metaanalysis", Journal of Applied Psychology, 87, 14-32.

Kramer, R.M. and Lewicki, R.L. (2010), "Repairing and enhancing trust: Approaches to reducing organizational trust deficits", Academy of Management Annals, 4, pp. 245_277.

Lagace, R.R. (1991), "An exploratory study of reciprocal trust between sales managers and salespersons", Journal of Personnel Selling and Sales Management, Vol. 11, pp. 49-58.

Landsbergis, P.A. (1988), "Occupational stress among health care workers: A test of the job demands-control model”, Journal of Organizational Behavior, Vol. 9, pp. 217-23.

Langford, P.H. (2003), "A one-minute measure of the Big Five? Evaluating and abridging Shafer's (1999) Big Five markers", Personality and Individual Differences, $35,1127-1140$.

Lau, C.M. and Tan, S.L.C. (2006), "The effects of procedural fairness and interpersonal trust on job tension in budgeting”, Management Accounting Research, 17, 171-186.

Lazarus, R.S. (1966), Psychological Stress and the Coping Process, Nueva York: McGraw Hill. 
Lazarus, R.S. and Folkman, S. (1984), Stress, appraisal, and coping, New York: Springer.

Lewicki, R. J., McAllister, D. J., and Bies, R. J. (1998), "Trust and distrust: New relationships and realities", Academy of Management Review, 23: 438-458.

Lewis, J. D. and Weigert, A. (1985), “Trust as a Social Reality”, Social Forces, Vol. 63, No. 4, pp. 967-985.

Lipowski, Z.J. (1975), "Physical illness, the patient, and his environment: psychosocial foundations in medicine", in M.F. Reiser, Organic Disorders and Psychosomatic Medicine. Vol. 4. American Hand-book of Psychiatry, Nueva York: Basic Book, pp. 342.

Locke, E.A. (1976), "The nature and causes of job satisfaction", in Dunnette, M.D. (Ed.), Handbook of Industrial and Organizational Psychology, Rand McNally, Chicago, IL, pp. 1297-349.

Lu. H., While. A.E., and Barriball, L. (2005), "Job satisfaction among nurses: a literature review”, International Journal of Nursing Studies, 42: 211-227.

Massey, G., and Kyriazis, E. (2007), "Interpersonal trust between marketing and R\&D during new product development projects", European Journal of Marketing, 41 (9/10), $1146-1172$.

Matzler, K. and Renzl, B. (2006), "The relationship between Interpersonal Trust, Employee Satisfaction, and Employee Loyalty”, Total Quality Management Vol. 17, No. 10, 1261-1271.

Mayer, R., Davis, J. H. and Schoorman, F. D. (1995), "An Integrative Model of Organizational Trust”, Academy of Management Review, Vol. 20, No.3, 709-734.

Mayer, R.C. and Gavin, M. B. (2005), "Trust in management and performance: Who minds the shop while the employees watch the boss?", Academy of Management Journal, 48: 874-888.

McAllister, D.J. (1995), "Affect- and cognition-based trust as foundations for interpersonal cooperation in organizations", Academy of Management Journal, Vol. 38, pp. 24-59.

McCauley, D.P. and Kuhnert, K.W. (1992), "A theoretical review and empirical investigation of employee trust in management", Public Administration Quarterly, Summer, 265-284.

McLean, A. (1979), Work Stress, Reading, MA: Addison-Wesley.

Mittal, B. (1996), "Trust and relationship quality: a conceptual excursion", Centre for Relationship Marketing Conference Proceedings, June, pp. 230-40. 
Molina-Morales, X., Martínez Fernández, M. T. and Torlò, V.J. (2011), “The Dark Side of Trust: The Benefits, Costs and Optimal Levels of Trust for Innovation Performance", Long Range Planning, Vol. 44, Issue 2, 118-133.

Montgomery, D.C, Blodgett, J.G. and Barnes, J.H. (1996), "A Model of Financial Securities Salespersons' Job Stress", The Journal of Services Marketing, Vol. 10, No. 3, pp. 21-38.

Mooradian, T., Renzl, B. and Matzler, K. (2006), "Who Trusts? Personality, Trust and Knowledge Sharing”, Management Learning 37(4): 523-40.

Motowidlo, S.J., Packard, J.S., and Manning, M.R. (1986), "Occupational stress: Its causes and consequences for job performance", Journal of Applied Psychology, Vol. 71, pp. 618-629.

Moye, J. and Henkin, B. (2006), "Exploring associations between employee empowerment and interpersonal trust in managers", Journal of Management Development, Vol. 25, pp. 101-117.

Newell, S. (2002), Creating the healthy organization: Well-being, diversity \& ethics at Work, London: Thomson Learning.

Nyhan, R.C. and Marlowe, H.A. (1997), "The psychometric properties of the organizational trust inventory", Evaluation Review, Vol 21, pp. 614-635.

Nyhan, R.C. (2000), "Changing the paradigm: trust and its role in public sector organizations", American Review of Public Administration, Vol. 30 No. 1, pp. 87-109.

Oh, Y., and Park, J. (2011), "New link between administrative reforms and job attitude: the role of Interpersonal trust in peers as a mediator on organizational commitment", International Review of Public Administration, Vol. 16, No. 3, pp. 65 - 87.

Ollo-López, A., Bayo-Moriones, A. and Larraza-Kintana, M. (2010), "The Impact of Country-Level Factors on the Use of New Work Practices", Journal of World Business, Vol. 46 No. 3, pp. 394-403.

Pennings, J. M., and Woiceshyn, J. (1987), “A typology of organizational control and its metaphors", In S. B. Bacharach \& S. M. Mitchell (Eds.), Research in the sociology of organizations, vol. 5: 75-104, Greenwich, CT: JAI Press.

Peiró, J.M. (1992), Desencadenantes del estrés laboral, Madrid: Eudema.

Peraita, C. and Pastor, M. (2000), "The primary school dropout in Spain: the influence of family background and labor market conditions", Education Economics, vol. 8, no.2, pp. 157-168.

Perry, R. and Mankin, L. (2007), "Organizational trust, trust in the chief executive and work satisfaction”, Public Personnel Management, Vol 36, pp 165-179. 
Podsakoff, P.M. and Organ, D.W. (1986), "Self-reports in organizational research: Problems and prospects", Journal of Management, 12: 531-544.

Rafferty, A.E. and Griffin, M.A. (2006), "Perceptions of organizational change: A stress and coping perspective", Journal of Applied Psychology, 91(5), 1154-1162.

Raghuram, S. and Wiesenfeld, B.M. (2004), "Work-nonwork conflict and job stress among virtual workers", Human Resource Management, Vol. 43, No. 2-3, pp. 259-278.

Rempel, J. K., Holmes, J. G., and Zanna, M. D. (1985), "Trust in close relationships", Journal of Personality and Social Psychology, 49: 95- 112.

Rhee, K.Y. (2010), "Different Effects of Workers' Trust on Work Stress, Perceived Stress, Stress Reaction, and Job Satisfaction between Korean and Japanese Workers", Safety and Health at Work; Vol. 1, No. 1, 87-97.

Rich, G. A. (1997), "The sales manager as a role model: effects of trust, job satisfaction and performance of salespeople", Journal of the Academy of Marketing Science, Vol. 25, pp. 319-328.

Rogelberg, S. G., Allen, J. A., Shanock, L., Scott, C. W., and Shuffler, M. (2010), "Employee satisfaction with their meetings: A unique predictor of job satisfaction", Human Resource Management, 49, 149-172.

Ross, A. (1994), "Trust as a moderator of the effect of performance evaluation style on job related tension: a research note", Accounting, Organisations and Society, 19 (7), 629-635.

Rousseau, D.M., Sitkin, S.B., Burt, R.S. and Camerer, C. (1998), "Not so different after all: a cross-discipline view of trust", Academy of Management Review, Vol. 23, No. 3, pp. 393-404.

Ruff, G.E. and Korchin, S.J. (1967), “Adaptive stress behavior”, in M.H. Appley and R. Trumbull, Psychological Stress, Nueva York: Aplleton-Century-Crofts, (pp.297-306).

Schill, T., Toves, C. and Ramanaiah, N. (1980), "Interpersonal Trust and Coping with stress", Psychological Reports, Vol. 47, pp. 1192.

Schmitt, M. (1996), "Uses and abuses of coefficient alpha", Psychological Assessment, 8(4), 350-353.

Schoorman, F. D., Mayer, R. C. and Davis, J. H. (2007), "An integrative model of organizational trust: past, present and future", Academy of Management Review, 32: 344-354.

Seaward, B.L. (2005), Managing stress: Principals \& strategies for health \& wellbeing, Sudbury, Massachusetts: Jones \& Bartlett Publishers. 
Seppänen, R., Blomqvist, K. and Sundqvist, S. (2007), "Measuring Interorganizational Trust: A Critical Review of the Empirical Research in 1990-2003", Industrial Marketing Management, 36 (2), 249-265.

Sheppard, B. and Sherman, D. (1998), "The Grammar of Trust: A Model and General Implications", The Academy of Management Review, Vol. 23, No.3, pp. 422-37.

Shah, D. V. (1998), "Civic engagement, interpersonal trust, and television use: An individual-level assessment of social capital”, Political Psychology, Vol. 19, pp. 469496.

Smith, P. C., Kendall, L. M., and Hulin, C. L. (1969), The measurement of satisfaction in work and retirement: A strategy for the study of attitudes, Chicago: Rand McNally.

Snelgrove, S.r. (1998), “Occupational stress and job satisfaction: A comparative study of health visitors, districts nurses and community psychiatric nurses", Journal of Nursing Management, 6(2), 97-104.

Spector, P.E. (1997), Job satisfaction: Application, assessment, causes, and consequences, Thousand Oaks, CA.: Sage.

Stacciarini, J.M.R. (2004), "Occupational stress and constructive thinking: Health and job satisfaction", Journal of Advanced Nursing, 46(5), 480- 487.

Stanton, J. M., Bachiochi, P. D., Robie, C., Perez, L. M., and Smith, P. C. (2002), "Revising the Jdi Work Satisfaction Subscale: Insights into Stress and Control", Educational and Psychological Measurement, 62(5), 877-895.

Sullivan, S. and Bhagat, R. (1992), "Organizational Stress, Job Satisfaction and Job Performance: Where Do We Go From Here?”, Journal of Management, Vol. 18, No.2, 353-374.

Sutherland, V.J. and Cooper, C.L. (1986), Man and accidents offshore - an examination of the costs of stress among workers on oil and gas rigs, Lloyds of London Press Ltd. Colchester, UK.

Swanson, V., Power, K., and Simpson, R. (1998), "A comparison of stress and job satisfaction in female and male GPs and consultants", Stress Medicine, 12(1), 17-26.

Tan, H. and Lim, A. (2009), "Trust in co-workers and trust in organizations", The Journal of Psychology, vol. 143, no. 1, pp. 45-66.

Terry, D.J., Nielsen, M. and Perchard, L. (1993), "Effects of work stress on psychological wellbeing and job satisfaction: the stress-buffering role of social support", Australian Journal of Psychology, Vol. 45 No. 3, pp. 168-75.

Ting, Y. (1997), "Determinants of Job Satisfaction of Federal Government Employees", Public Personnel Management, 26(3): 313-334.

Ulleberg, P. and Rundmo, T. (1997), "Job stress, social support, job satisfaction and absenteeism among offshore oil personnel”, Work \& Stress, Vol. 11(3), 215-228. 
Wanous, J., Reichers, A. and Hudy, M. (1997), "Overall job satisfaction: how good are single item measures?”, Journal of Applied Psychology, 82, pp. 247-252.

Weinberg, A., Cooper, C. and Sutherland, V.J. (2010), Organizational Stress Management: A Strategic Approach, Palgrave Macmillan, November 2010.

Wetzel, C.M., Kneebone, R.L., Woloshynowych, M., Moorthy, K., and Darsy, A.D. (2006), "The effects of stress on surgical performance", The American Journal of Surgery, 191(1), 5-10.

Wu, W. L., Lin, C. H., Hsu, B. F. and Yeh, R. S. (2009), "Interpersonal trust and knowledge sharing: Moderating effects of individual altruism and a social interaction environment", Social behavior and personality, Vol. 37, No. 1, pp. 83-94.

Zahra, S., Yavuz, R.I. and Ucbasaran, D. (2006), "How much do you trust me? The dark side of relational trust in new business creation in established companies", Entrepreneurship Theory and Practice, 30(4), 541-559. 
Figure 1. Conceptual model.

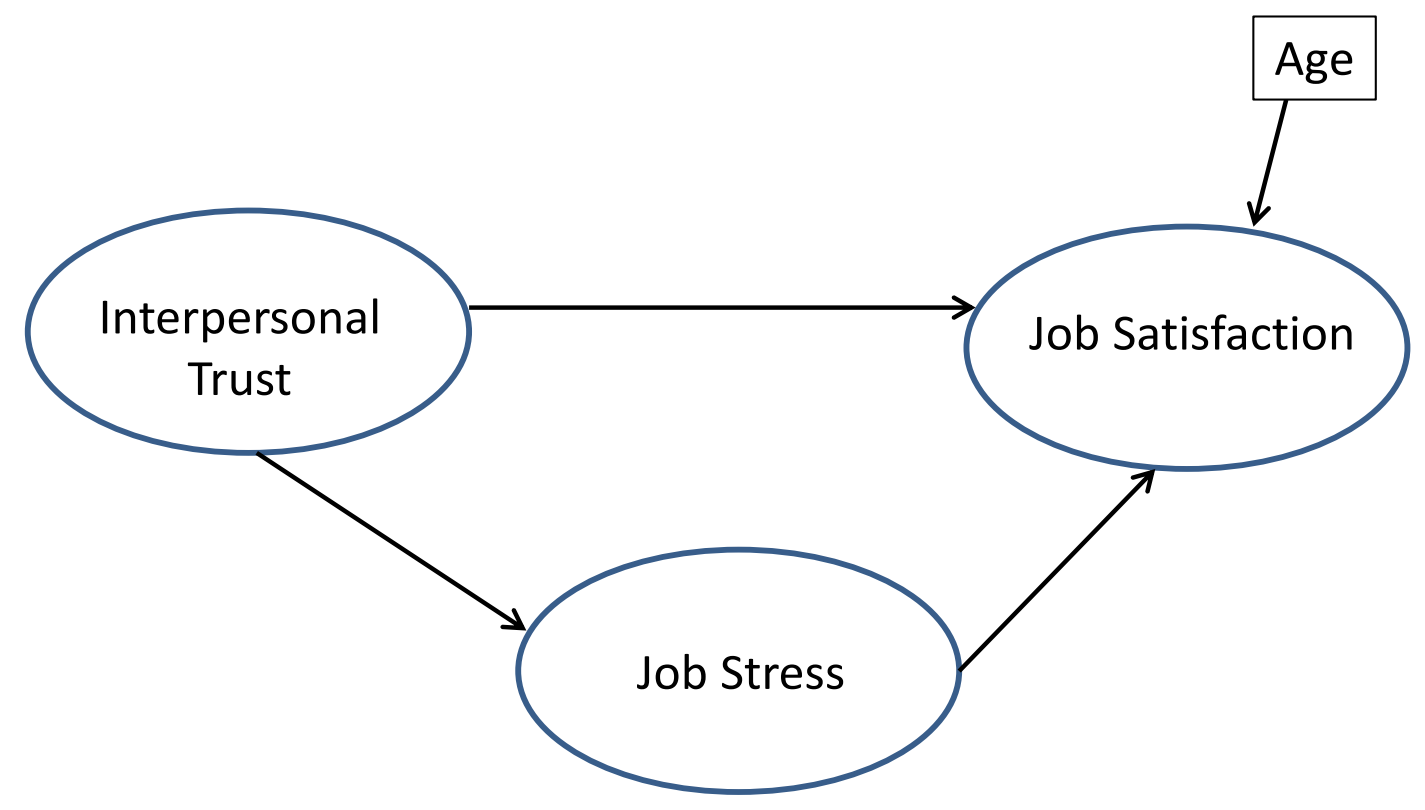


Figure 2. Results of the Mediated Model.

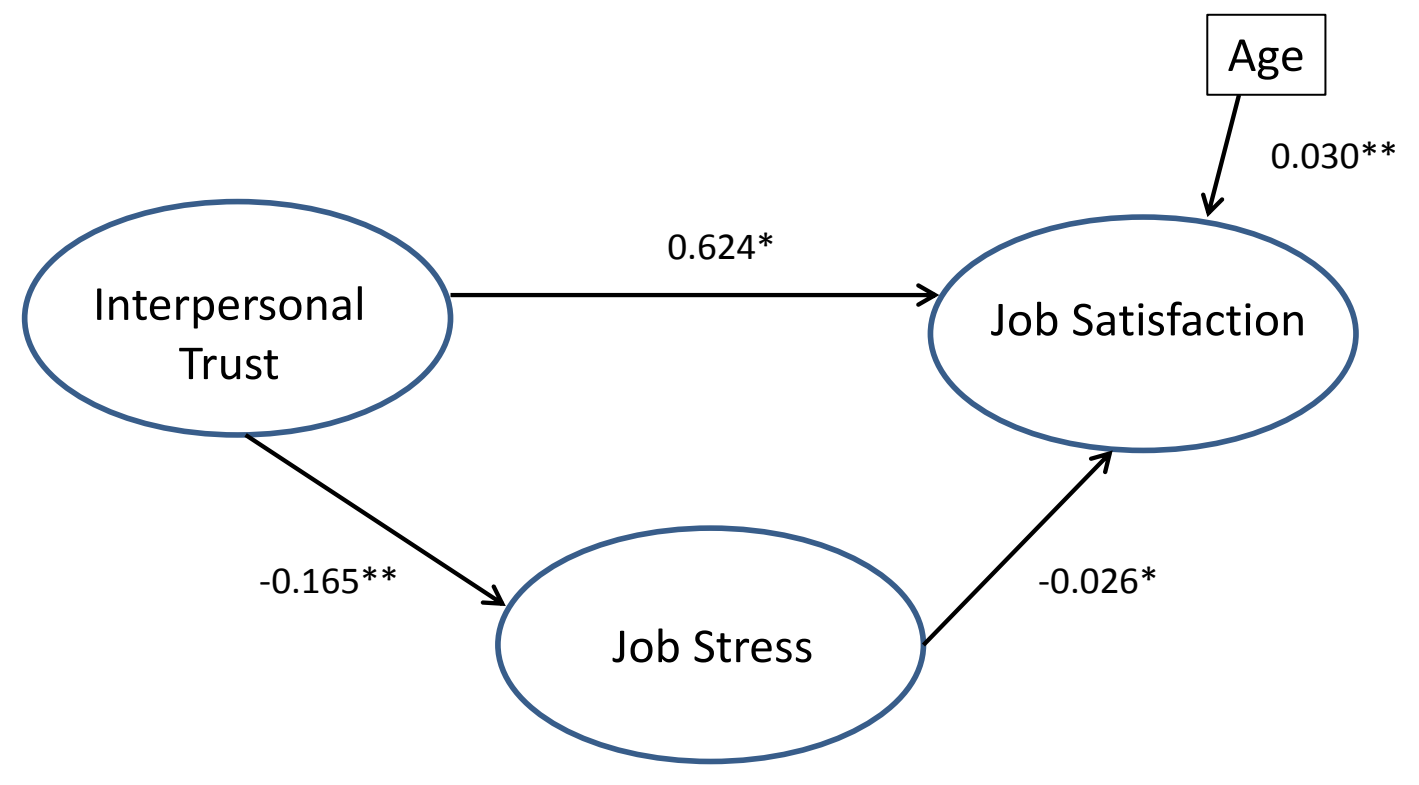

Note: ${ }^{*} p<.05 .{ }^{* *} p<.01$. 
Table 1. Descriptive statistics and correlations $(N=6,407)$

\begin{tabular}{|c|c|c|c|c|c|c|c|}
\hline Variables & Mean & s.d. & 1 & 2 & 3 & 4 & 5 \\
\hline 1. Employee age & 41.04 & 10.707 & 1 & & & & \\
\hline 2. Trust in superiors & 7.13 & 2.343 & $0.033^{* *}$ & 1 & & & \\
\hline 3. Trust in co-workers & 7.85 & 1.797 & -0.002 & $0.504^{* *}$ & 1 & & \\
\hline 4. Job stress & 5.51 & 3.046 & -0.003 & $-0.139^{* *}$ & $-0.092^{* *}$ & 1 & \\
\hline 5. Job satisfaction & 7.22 & 1.619 & $0.045^{* *}$ & $0.519^{* *}$ & $0.384^{* *}$ & $-0.129^{* * *}$ & 1 \\
\hline
\end{tabular}

Note: $* * p<0.01 ; * p<0.05$ (two-tailed) 
Table 2. Fit indices for the structural models

\begin{tabular}{lllllll}
\hline Model & $\begin{array}{l}\text { Satorra-Bentler } \\
\text { Chi-Square }\end{array}$ & d.f. & $p$ & $\begin{array}{l}\text { Bentler-Bonnet } \\
\text { Non-Normed Fit }\end{array}$ & $\begin{array}{l}\text { Index Comparative root mean square error } \\
\text { Fit Index }\end{array}$ & $\begin{array}{l}\text { of approximation } \\
\text { Direct effect model }\end{array}$ \\
\hline Mediated model & 10.668 & 2 & 0.007 & 0.992 & 0.997 & 0.998 \\
Constrained model & 1612.37 & 4 & 0.032 & 0.995 & 0.448 & 0.016 \\
\hline
\end{tabular}

